\title{
Determination of Calcium and Magnesium by Atomic Absorption
}

Spectrophotometry and Its Application to the Water Analyses ${ }^{\dagger}$

\author{
Ryozo Nakagawa, Yoshiki Nanbu and Yoshihiko Ohyagi \\ Department of Chemistry, Faculty of Science, Chiba University; Yayoi-cho, Chiba-shi, Japan
}

Atomic absorption spectrophotometric investigations of calcium and magnesium, with airacetylene flame, were carried out by the use of Shimadzu Multichannel Atomic AbsorptionFlame Spectrometer, Model MAF-1, and fundamental conditions were examined with an aim of its application to the analysis of calcium and magnesium in water.

The condition recommended for calcium and magnesium determination were as follows, wavelength ; $4227 \AA$ and $2852 \AA$, hollow cathode lamp current ; $11 \mathrm{~mA}$ and $10 \mathrm{~mA}$, slit width ; $0.05 \mathrm{~mm}$ and $0.05 \mathrm{~mm}$, acetylene pressure ; $0.3 \mathrm{~kg} / \mathrm{cm}^{2}$ and $0.3 \mathrm{~kg} / \mathrm{cm}^{2}$, air pressure; $1.4 \mathrm{~kg} / \mathrm{cm}^{2}$ and $1.4 \mathrm{~kg} / \mathrm{cm}^{2}$, respectively.

Coexisting elements except large amounts of silicon, aluminium, titanium and vanadium did not interfere the determination. Chemical interference could be minimized on calcium by the addition of $5000 \mathrm{ppm}$ of lanthanum to the unknown and standard samples, same interference to magnesium could be minimized by the addition of $50 \mathrm{ppm}$ of calcium.

The relative determinations were less than $4.7 \%$, and the results were satisfactorily coincident with those obtained by other methods.

$\dagger$ Studies on the Analysis of Pollution Samples using Atomic Absorption Spectrophotometry. II.

（日本化学会誌, 1972, p. $66 \sim 71$ )

\section{限界電流測定法による硫酸チタン $(\mathbf{I I I})$ 線量計}

\author{
(1971 年 9 月 8 日受理)
}

後藤 正 志・井戸田 義雄・石 井 大道*

硫酸チタン(III)の硫酸酸性溶液火 $r$ 線照射を行なうと，チタン(II)は水の放射線分解生成物によってチタン(N)ヘ

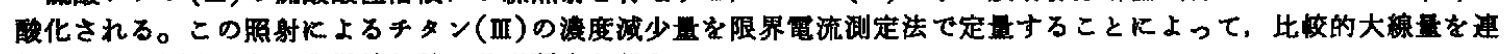

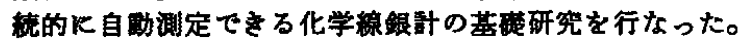

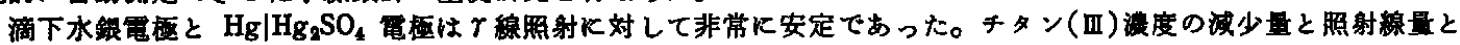

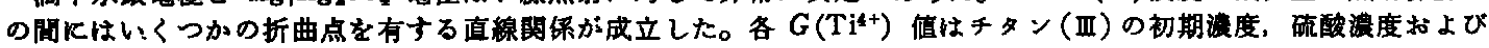

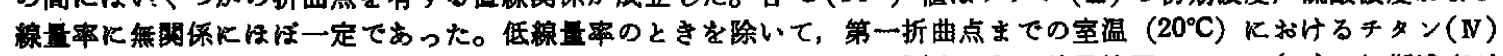
生成の $G$ 值 $\left(G_{1}\left(\mathrm{Ti}^{4+}\right)\right)$ は $5.76 \pm 0.13$ と精度のよい值が得られた。剆定できる線量範囲はチタン(III)の初期浱度が 大きくなるにうれて增大し， $42 \mathrm{mmol} / l$ の溶液を用いれは $2 \times 10^{8} \mathrm{rad}$ の線量まで测定可能になった。また，一度使

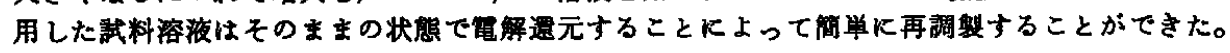

\section{1 㒂}

$r$ 線の線量測定法として，現在もっとも標準的に用いられてい るのは硫酸鉄 (II) 線量計) (Fricke 線量計) であるが，これは $0.8 \mathrm{~N}$ 硫酸溶液中の溶存酸素の量に応して線量測定できる範囲が 限定されている。すなわち空気飽和の埸合においては $5 \times 10^{4} \mathrm{rad}$, 酸素飽和の揚合では $2 \times 10^{8} \mathrm{rad}^{2)}$ まで湘定可能とされている。大 線量揤定用としては硫酸セリウム (N) 線量計"3) および硫酸鉄 (II)

* 名古留大学工学部応用化学教室, 名古屋市千種区不老町

1) J. Weiss, Int. J. Appl. Radiat. Isotopes, 4, 89(1958).

2）団野晧文，同位体之放射線，3，489(1960).

3) G. R. A. Johnson, J. Weiss, Proc. Roy. Soc., 240, 189 (1957).
と硫酸鋼(II)による方法)が報告されている。しかしこれらは 再現性火多くの問題点が残されている。最近では硫酸チタン(N) と水の放射線分解生成物の過酸化水素之の錯体形成反沁着目し

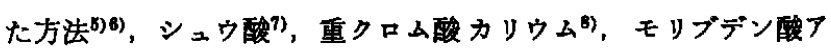
ンモニウムク，その他10)を用いた線量計が発表されている。測定

4) E. J. Hart, P. P. Walsh, Rad. Res., 9, 127(1958).

5) T. Shiokawa, K. Hasegawa, Nature, 195, 592(1962).

6) K. Hasegawa, Radioisotopes, 16, 423(1967).

7) I. Draganic, Nucleonics, 21, 33(1963).

8) T. Asai, S. Ikeguchi, Radioisotopes, 14, 73(1965).

9) P. M. Oza, P. S. Rao, Bull. Chem. Soc. Jap., 40, 239 (1967).

10) S. N. Bhattacharyya, K. N. Dutta, J. Sci. Ind. Res.,

26, 147 (1967). 
手段として上記の線量計はいずれる比色法であり， $\mathrm{pH}$ 澌定 ${ }^{11)}$

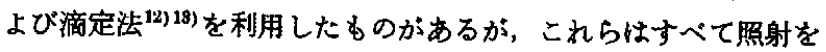
止めたのち測定するものである。一方，連続的測定法としてはガ スクロマトグラフィーを利用したもの ${ }^{14)}$ ，電気化学的方法による

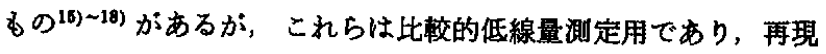
性にも閣題点が多い。

したがって本研究では比较的大線量を精度よく連続的に自動測 定することを目的として，硫酸チタン（III）溶液を用い限界䉓流測 定法により線量測定を武みた。

\section{2 原}

\section{理}

チタン(III)は水溶液中でよく用いられる罯元郕であり，水の放 射線分解生成物 $\left(\cdot \mathrm{H}, \cdot \mathrm{OH}, \mathrm{H}_{2} \mathrm{O}_{2}, \mathrm{H}_{2}\right)$ と反応してチタン (N)へ 酸化される。また，千タン(III) 硫酸酸性溶液中で約 $-0.55 \mathrm{~V}$ (vs. $\mathrm{Hg} \mid \mathrm{Hg}_{2} \mathrm{SO}_{4}$ ) の半波䉓位をすつポーラログラムを示す。そこ でチタン(III)を含む硫酸酸性溶液に $r$ 線を照射して生じるチタン (III)漫度の減少量を限界流測定法で測定することによって，照射 線量を知ろらとっるものである。

\section{3 実験および結果}

\section{1 試}

チタン(III)の原料としては硫酸チタン (III) $\left(\mathrm{Ti}_{2}\left(\mathrm{SO}_{4}\right)_{8} \cdot 8 \mathrm{H}_{2} \mathrm{O}\right)$ の市販一級品を用いた。酸酸、シュウ酸チタンカリウム $\left(\mathrm{K}_{2} \mathrm{TiO}\right.$. $\left.\left(\mathrm{C}_{2} \mathrm{O}_{4}\right)_{2} \cdot 2 \mathrm{H}_{2} \mathrm{O}\right)$ 扰よびシュウ酸はいずれも特級試薬を用いた。水 は蒸留後イオン交換樹脂柱を通したるのを使用した。

\section{2 装 置}

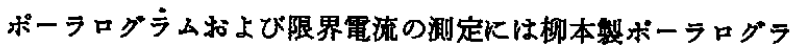
フを使用した。䉓極としては指示電極に滴下水銀を，参照電極に $\mathrm{Hg} \mid \mathrm{Hg}_{2} \mathrm{SO}_{4}$ (固体)， $\mathrm{K}_{2} \mathrm{SO}_{4}$ (飽和) 電極を用い，塩橋として硫酸 カリウムを飽和させた寒天橋を使った。なお，滴下水銀電極の特 性恃加電仕をかけない状態で $m=0.712 \mathrm{mg} / \mathrm{sec}, t=5.25 \mathrm{sec}(P$ $=68.5 \mathrm{~cm})$ であった。電解塄元和上び照射用の七ルは図 1 K示 すような上部をすりあわせにし，底部分を細管で補助せル飞連結 した硬質ガラス製の容器を試作した。なお゙，図１は を示したものである。 $r$ 線源としては $4 \mathrm{kCi}$ の ${ }^{80} \mathrm{Co}$ を利用した。

\section{3 チタン (III) 試料溶液}

3.3.1 チタン(III) 溶液の調製法：硫酸チタン(III)の道当量を 硫酸水溶液に加熱溶解し，冷却したのち不溶解分を口別して試料 原液とする。このチタン溶液は酸瀑度が薄い之加水分解するので， 硫酸激度を $8 \mathrm{~N}$ 程度に瀑くして保存しておく。なお，上記原液

11) M. Wakabayashi, G. Irie, S. Shibata, S. Kawanishi, K. Suzaki, T. Sugawara, E. Yamada, N. Iwasaki, H. Mitsuhashi, O. Oyama, J. Rad.Res. Jap., 4, 68(1963).

12) J. Teply, J. Bedner, Int. Conf. Peaceful Uses Atom. Energy, 29, 71(1958).

13) G. V. Taplin, "Radiation Chemistry", Academic Press Inc., New York (1956)ch. 8.

14) R. H. Prosch, H. Bildstein, Int. J. Appl. Radiat. Isotopes, $16,56(1965)$.

15) G. Z. Gochaliev, T. I. Zalkind, V. I. Veselovskii, Dokl. Akad. Nauk SSSR, 132, 872(1960).

16) Idem., ibid., 146, 131(1962).

17) S. Z. Lewis, R. H. Koslow, U. S. P., 3, 179, 581(1965).

18) R. F. Sympson, W. D. Hunter, Anal. Chem., 41, 2064 (1969).

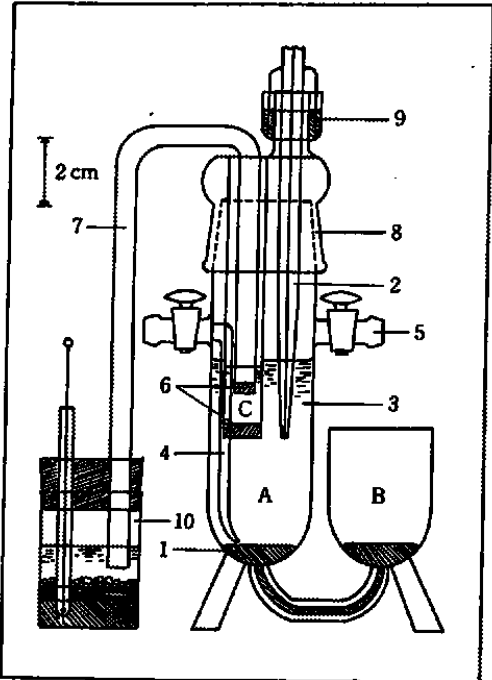

Fig. 1 Cell for electrolytic reduction and irradiation (in the condition of irradiation)

1 : Mercury for electrolytic reduction, 2 : Dropping mercury electrode, 3 : Sample solution, $4: \mathrm{N}_{2}$ gas inlet, $5: \mathrm{N}_{2}$ gas outlet, 6 : Sintered glass, $7:$ Salt bridge, 8 : Ground glass joint, 9 : Mercury for seal, $10: \mathrm{Hg} ! \mathrm{Hg}_{2}$. $\mathrm{SO}_{4}$ (solid), $\mathrm{K}_{2} \mathrm{SO}_{4}$ (sat.) reference electrode

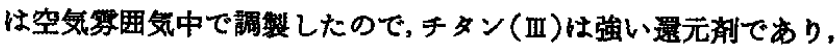
空気酸化を受けてほとんどチタン(V)炕変化している。そこで使 用前化還元する必要があるので, チタン(N)溶液の液状アマルガ ム還元法扰よび電解薑元法について検䣓した。その結果，前者で

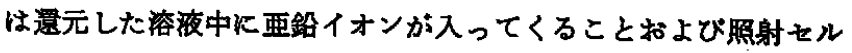
に液を移すさいどうしてる空気低螌れるなど知点があった。し たがって本実験では水銀を陰極とする電解這元法によってキタン (III)試料溶液を調製することにした。その操作法としては，まず

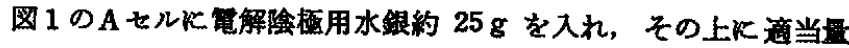
の誧料液を注入する。つぎにらたの受ザラ(9)に密閣用水銀を入 れ、Cせルに同じ試料液を入れたのちふたをし，図のように滴下 水銀電極を择入する。そして陽極の鉛板をC七ル中へ入れ，Bセ ルの水銀中へ白金線を挿入して章線とする。以上で蕉備を終え， 除酸素した窒素ガスを通気しながら，整流器を用い両極間に 11 〜12 V の電压をかけて 0.2〜0.4A の電流を通し，各チタン浱 度に応して 20〜25 分間電解賟元を行なう。なお，窒素ガスの除 酸素は 2 個の水酸化ナトリウムを飽和したピロガロール洗浄液中 を通すことによって行なった。キタン(N)は硫酸酸性溶液中で約

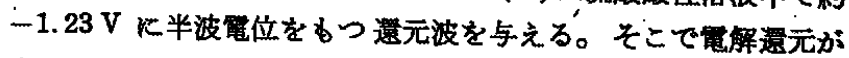
完了したかとらか忙この波を利用し，試料液のポーシログラムを 測定することによって検定した。

恶元が完了したら，ただちに鉛板を取出してCセル中の酸素を 含んだ陽極夜をスポイドで吸い出す。その後 2〜3 度セル内を試 料液で洗い，しばらく故展しておくと半溶歌ガラスを通ってAセ ル内の液が少量C七ル内へ浸入してくる。その液む吸い出し，空 来ガスを通気しながら約 20 分間放算する。この操作によって西 解のさい生成した還元液中の水类を除去すると同時に上昇した液 温を室温 $\left(20^{\circ} \mathrm{C}\right)$ まで下げる。その間にCセル内に適当量の波が 上昇してくるので,この中へ参照電極の寒天橋を㨉入し，笔莱カ スのコックを閉してて試料溶液の調製を完了する。 
3.3.2 チタン(III) 溶液の滣度決定および検量線：硫酸チタン （III)は吸湿性であり，また水溶液中で容易に溶存酸素によって酸 化される。そこで硫酸チタン(II)原液の瀆度は空気酸化によって 完全にチタン(N)にかえたのち， $0.2 \mathrm{~mol} / l$ シュウ酸を支持電解 留とするポーラログラフ法によりチタン $(\mathbb{N})$ 浱度を定照すること によって決定した。なお，このさいの標準物筫としてはシュウ酸 キタンカリウムを用いた。

漫度既知の原液を水で逼当に希釈した溶液を用いて，前節の電 解還元法により各種㳻度のチタン（II）溶液を調製し，そのまま四 1 のセルで室温 $\left(20^{\circ} \mathrm{C}\right)$ K拈いてポーラログラムを測定した。 $0.8 \mathrm{~N}$ 硫酸中でのチタン(III)濃度と酸化波の波高との関保を図 2 К示す。このように雨者の間には良好な比例関俰が成立した。

3.3.3 チタン(III) 溶湤の安定性: 電解還元法によって調製し たチタン(II) 溶液の室温 $\left(20^{\circ} \mathrm{C}\right)$ での放置時間之酸化波高の減少 量（チタン(N)の生成量）の関係を図3に示す。このよらにチタ ン(III) 溶液は本セルを用いれば約 50 時間は空気酸化に対して安 定である。しかし，因3に付記したよ5K，Cセル中の陽極液を 吸い出すことなくそのまま放置すると短時間のうちに酸素酸化を 受けることが明らかたなった。

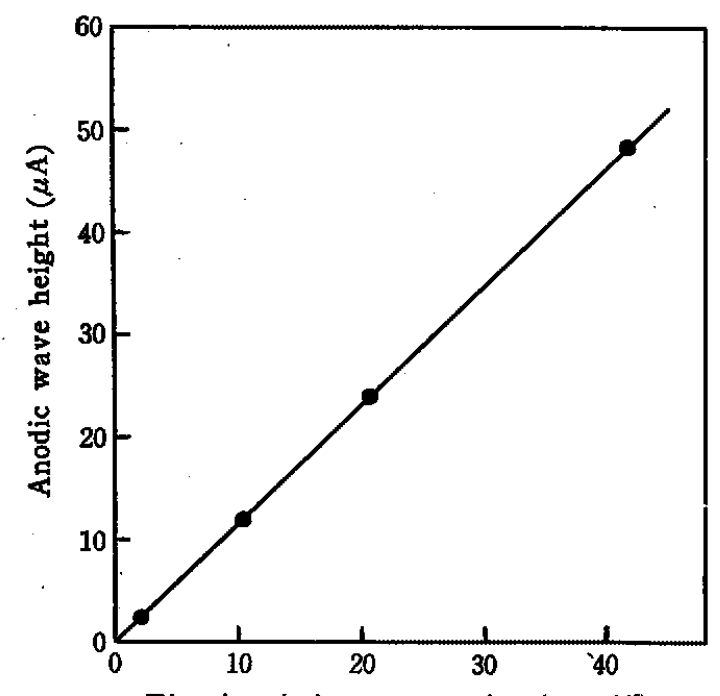

Titanium (II) concentration ( $\mathrm{mmol} / \mathrm{l}$ )

Fig: 2 Relation between titanium (II) concentration and anodic wave height in $0.8 \mathrm{~N}$ sulfuric acid

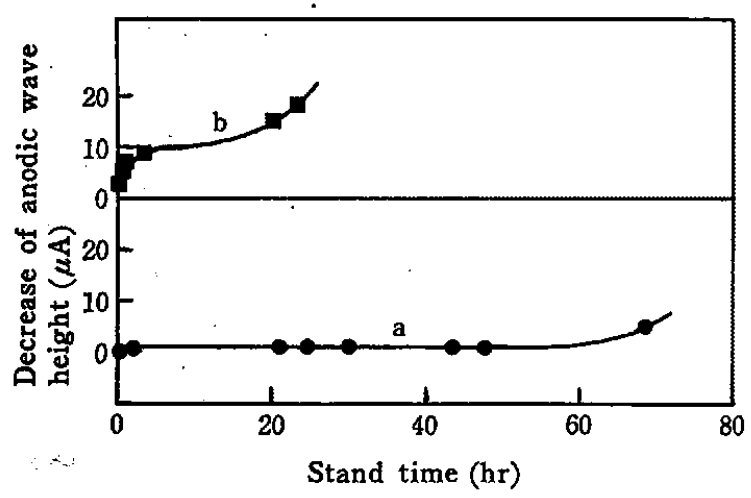

Fig. 3 Relation between stand time after electrolytic reduction of titanium(II) solution and decrease of anodic wave height

a : In removing anode solution

$\mathrm{b}:$ In standing anode solution

\section{4 照射実験}

3.4.1 ボーラログラフィーによる 基硭条件の検討：3.3.1で 調製したチタン $(\mathrm{m})$ 試料溶液を $\gamma$ 線照射室の所定の位置へ図 1 の ように設置する。滴下水銀電極恃長時間使用しても水銀柱高が性 とんど変化しないように横に広い体積の大きな水銀だめを使用し

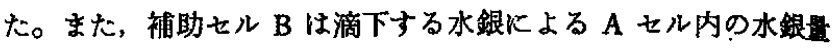
（高さ）特よび王力の增大に対して䜌衝作用を果たすよ5に工夫 した。各電極端子㹥照射室外へ導き， $r$ 線を照射しながら室温 $\left(20^{\circ} \mathrm{C}\right)$ でポーラログラムを記録した。なお，試料溶液の温度㤃 $r$ 線照射によって多少上昇するが，本実験条件下では最大で約 $5^{\circ} \mathrm{C}$ であり，波高にはあまり影響がないと考えられる。線量率が 2.0 $\times 10^{\mathrm{r}} \mathrm{rad} / \mathrm{hr}$ の位置に和ける照射前, 20 時間和よび 30 時間照 射時のポーラログラムの亲化を図 4 に示す。この上5に照射時で も再現性のある良好なポーラログラムが得られ，滴下水銀電極扰 よび $\mathrm{Hg} \mid \mathrm{Hg}_{2} \mathrm{SO}_{4}$ 電極性ともに った。また，予想と和り照射時間とともに酸化波の波高が減少し て還元波のそれが增大し，チタン（II）性照射によってチタン（N) に変化することが明らかになった。

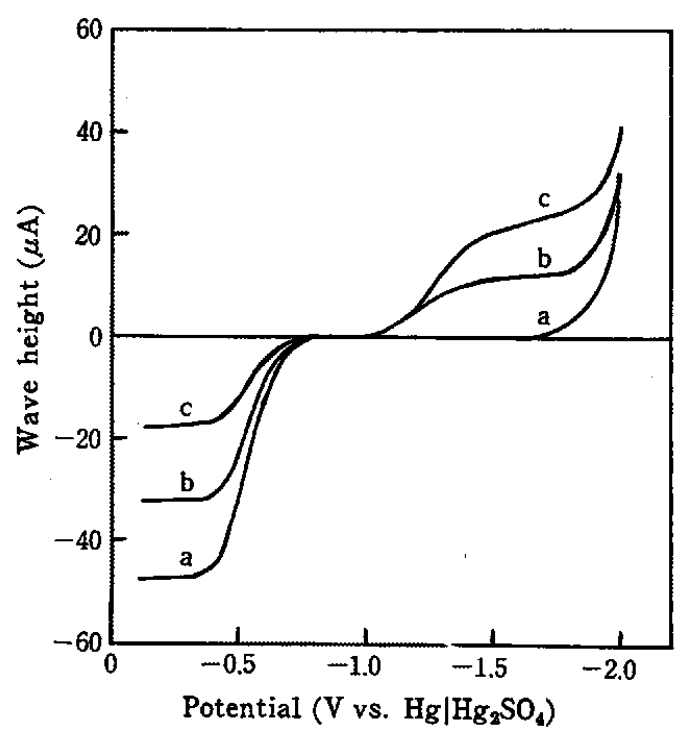

Fig. 4 Change of polarogram by $\gamma$-rays irradiation Irradiation time of $\gamma$-rays $(\mathrm{hr}) \longrightarrow a: 0, b: 20, c: 30$ Initial titanium(II) concentration $: 42 \mathrm{mmol} / l$ Sulfuric acid concentration : $0.8 \mathrm{~N}$

Dose rate $: 2.0 \times 10^{5} \mathrm{rad} / \mathrm{hr}$

3.4.2 限界電流測定法による 楾測定：ポーラログラフィー による検討結果に基づき，線量測定を完全に連続化するため限界 電流測定法の適用を試みた。すなわち，滴下水鐙電極の電位をチ タン(III)の限界電流が得られる $-0.30 \sim-0.40 \mathrm{~V}$ に設定し, 照 射火よる電流値の経時変化を自動記録することによって以下の娭 討を行なった。

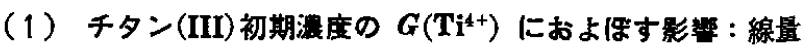
率を $2.0 \times 10^{5} \mathrm{rad} / \mathrm{hr}$ ，硫酸滣度を $0.8 \mathrm{~N}$ の一定の条件下で， 千 タン(II)の初期灌度を変化させたときの照射線量とチタン(II) 灌 度（電流値）の娍少量との関係の代表例を図 5 亿示す。このよ に照射線量とチタン(II) 数度の減少量との間には何段かの折曲点 のある直線関係が成立し，チタン(III)の初期濃度が小さい注と低 い線量で直線が折れる。これらのキタン（III）の初期䈨度のG. 


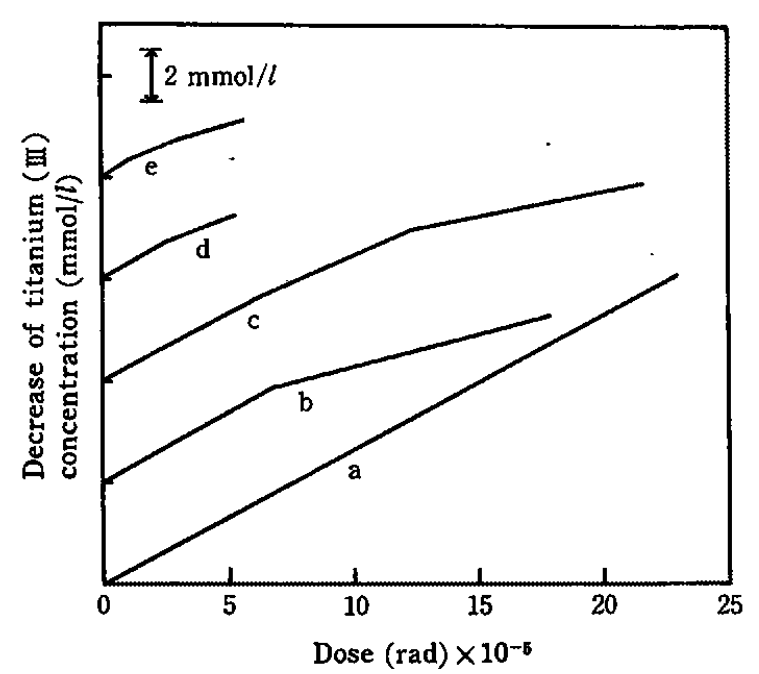

Fig. 5 Relation between dose irradiated and decrease of titanium( (II) concentration on changing initial titanium (III) concentration

Initial tftanium(III) concentration ( $\mathrm{mmol} / \mathrm{l})$ a : 42 , b: 21, c $: 10.5, \mathrm{~d}: 4.2$, e $: 2.4$ Dose rate $: 2.0 \times 10^{5} \mathrm{rad} / \mathrm{hr}$, Sulfuric acid concentration : $0.8 \mathrm{~N}$

$\left(\mathrm{Ti}^{4+}\right)$ におよぼす影㗽を表 1 にまとめて示す。ここで $\mathrm{G}_{1}\left(\mathrm{Ti}^{4+}\right)$ ， $G_{2}\left(\mathrm{Ti}^{4+}\right)$ はそれそれれ最初から第一折曲点まで，第一から第二折 曲点までの間のチタン $(\mathrm{N})$ 生成の $G$ 值であり, $\left(\mathrm{Ti}^{3+} / \mathrm{Ti}^{\mathbf{4}}\right)_{1}$, $\left(\mathrm{Ti}^{3+} / \mathrm{Ti}^{4+}\right)_{2}$ はそれぞれ第一，第二折曲点でのチタン(III) とキタ ン(N) の灌度比を表わす。なおこのさいの $r$ 線量率としては Fricke 線量計で求めた值を用いた。このように $G\left(\mathrm{Ti}^{4+}\right)$ は 2.4 〜 $42 \mathrm{mmol} / l$ の濃度範囲でチタン (III)の初期熳度に無関係に一定 であった。

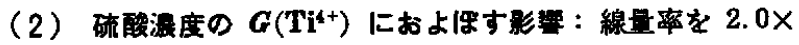

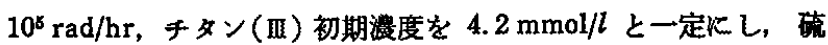

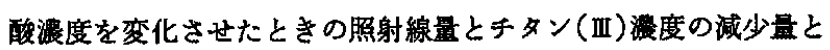
の関係を調べた。その結果を図 6 および表 2 に示す。このように

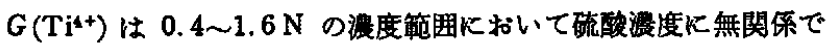
あった。

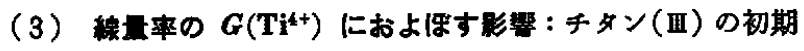

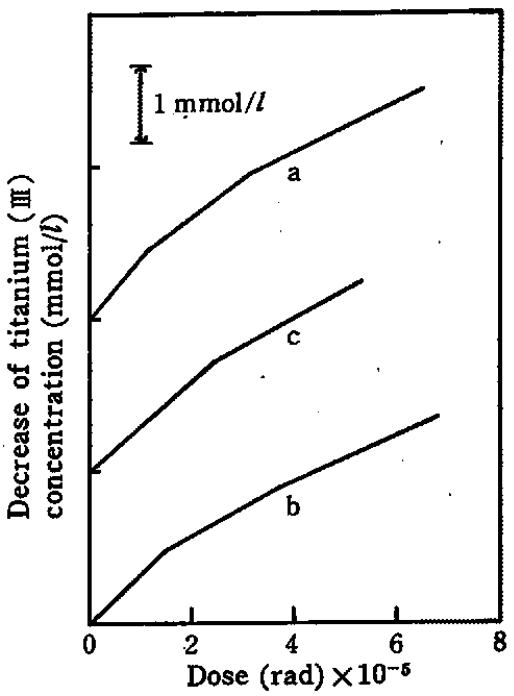

Fig. 6 Relation between dose irradiated and decrease of titanium (III) concentration on changing sulfuric acid concentration

Sulfuric acid concentration $(N)-a: 0.4, b: 0.8, c: 1.6$ Dose rate : $2.0 \times 10^{5} \mathrm{rad} / \mathrm{hr}$

Initial titanium(III) concentration : $4.2 \mathrm{mmol} / l$

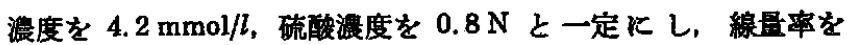
$0.27 \times 10^{6} \sim 9.5 \times 10^{6} \mathrm{rad} / \mathrm{hr}$ と変化させて $G\left(\mathrm{Ti}^{\mathrm{k}+}\right) \mathrm{K}$ 対する影

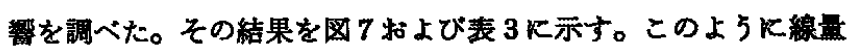
率が $0.27 \times 10^{5}$ と小さいときには線量とチタン(四)淽度減少量と の間には最初に傾斜の急な別の部分が観察された。この部分のG 值を $G_{0}\left(\mathrm{Ti}^{++}\right)$と表わす。，しかし，線量率が $0.41 \times 10^{6} \mathrm{rad} / \mathrm{hr}$ 以 上の位㯰では $G\left(\mathbf{T i}^{\mathbf{4}}\right)$ は線量率によらず一定であった。

また, 各折曲点のチタン (III) とチタン（N) の灙度比すチタン

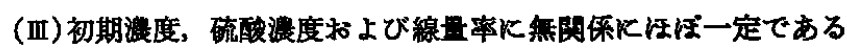
と考えられる。

以上の結果炕基ついて全データを用いG值および各折曲点のチ

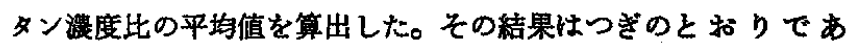
る。

$G_{0}\left(\mathrm{Ti}^{4+}\right)=8.06 \pm 1.65, \quad G_{1}\left(\mathrm{Ti}^{4+}\right)=5.76 \pm 0.13, \quad G_{2}\left(\mathrm{Ti}^{4+}\right)=$ $3.86 \pm 0.49, \quad\left(\mathrm{Ti}^{3+} / \mathrm{Ti}^{4+}\right)_{1}=2.65 \pm 0.84, \quad\left(\mathrm{Ti}^{8+} / \mathrm{Ti}^{4+}\right)_{2}=1.15 \pm$ 0.31

Table 1 Effect of initial titanium (III) concentration on $G\left(\mathrm{Ti}^{4+}\right.$ ) value

\begin{tabular}{|c|c|c|c|c|c|c|c|}
\hline $\begin{array}{l}\text { Exp. } \\
\text { No. }\end{array}$ & $\begin{array}{l}\text { Initial } \mathrm{Ti} \\
\text { conc. } \\
(\mathrm{mmol} / \mathrm{l})\end{array}$ & $\begin{array}{l}\text { II) dose rate } \\
\begin{array}{l}(\mathrm{rad} / \mathrm{hr}) \\
\times 10^{-8}\end{array}\end{array}$ & $\begin{array}{l}\text { conc. } \\
\text { (N) }\end{array}$ & $G_{1}\left(\mathrm{Ti}^{4+}\right)$ & $\begin{array}{c}G_{2}\left(\mathrm{Ti}^{4+}\right) \\
.\end{array}$ & $\left(\mathrm{Ti}^{3+} / \mathrm{Ti}^{4+}\right)_{1}$ & $\left(T \dot{i}^{8+} / T i^{4+}\right)_{2}$ \\
\hline 6 & 42 & 2.0 & 0.8 & 5.60 & 3.92 & 2.26 & 0.64 \\
\hline 4 & 21 & 2.0 & 0.8 & 5.74 & 3.15 & 2.86 & - \\
\hline 5 & 10.5 & 2.0 & 0.8 & 5.66 & 4.24 & 3.24 & 1.18 \\
\hline 4 & 4.2 & 2.0 & 0.8 & 5.78 & 3.76 & 1.97 & 1.46 \\
\hline 2 & 2.4 & 2.0 & 0.8 & 5.77 & 3.96 & 2.13 & 0.72 \\
\hline
\end{tabular}

Table 2 Effect of sulfuric acid concentration on $G\left(\mathrm{Ti}^{4+}\right)$ value

\begin{tabular}{|c|c|c|c|c|c|c|c|}
\hline $\begin{array}{l}\text { Exp. } \\
\text { No. }\end{array}$ & $\begin{array}{l}\text { Initial } \mathrm{Ti} \\
\text { conc. } \\
\text { (mmol/l) }\end{array}$ & $\begin{array}{l}\text { II) dose rate } \\
(\mathrm{rad} / \mathrm{hr}) \\
\times 10^{-5}\end{array}$ & $\begin{array}{l}{ }_{4} \text { conc. } \\
(\mathrm{N})\end{array}$ & $G_{1}\left(\mathrm{Ti}^{4+}\right)$ & $G_{2}\left(\mathrm{Ti}^{4+}\right)$ & $\left(\mathrm{Ti}^{3+} / \mathrm{Ti}^{4+}\right)_{1}$ & $\left(\mathrm{Ti}^{8+} / \mathrm{Ti}^{4+}\right)_{2}$ \\
\hline 2 & 4.2 & 2.0 & 0.4 & 5.90 & 4.42 & 2.99 & 1.34 \\
\hline 4 & 4.2 & 2.0 & 0.8 & 5.78 & 3.76 & 1.97 & 1.46 \\
\hline 3 & 4.2 & 2.0 & 1.6 & 5.81 & 3.96 & 2.47 & 1.35 \\
\hline
\end{tabular}


Table 3 Effect of dose rate on $G\left(\mathrm{Ti}^{4+}\right)$ value

Exp. Initial Ti (II) dose rate $\mathrm{H}_{2} \mathrm{SO}_{4}$ conc.

\begin{tabular}{ccccccccc} 
No. & $\begin{array}{c}\text { conc. } \\
(\mathrm{mmol} / \mathrm{l})\end{array}$ & $\begin{array}{c}(\mathrm{rad} / \mathrm{hr}) \\
\times 10^{-5}\end{array}$ & $(\mathrm{~N})$ & $G_{0}\left(\mathrm{Ti}^{4+}\right)$ & $G_{1}\left(\mathrm{Ti}^{4+}\right)$ & $G_{2}\left(\mathrm{Ti}^{4+}\right)$ & $\left(\mathrm{Ti}^{3+} / \mathrm{Ti}^{4+}\right)_{1}$ & $\left(\mathrm{Ti}^{3+} / \mathrm{Ti}^{4+}\right)_{2}$ \\
\hline 3 & 4.2 & 0.27 & 0.8 & 8.06 & 5.85 & 4.41 & 3.41 & 1.06 \\
4 & 4.2 & 2.0 & 0.8 & - & 5.78 & 3.76 & 1.97 & 1.46 \\
2 & 4.2 & 9.5 & 0.8 & - & 5.85 & 3.73 & 2.39 & 1.48 \\
2 & 6.6 & 0.41 & 0.8 & - & 5.90 & 3.50 & - & -
\end{tabular}

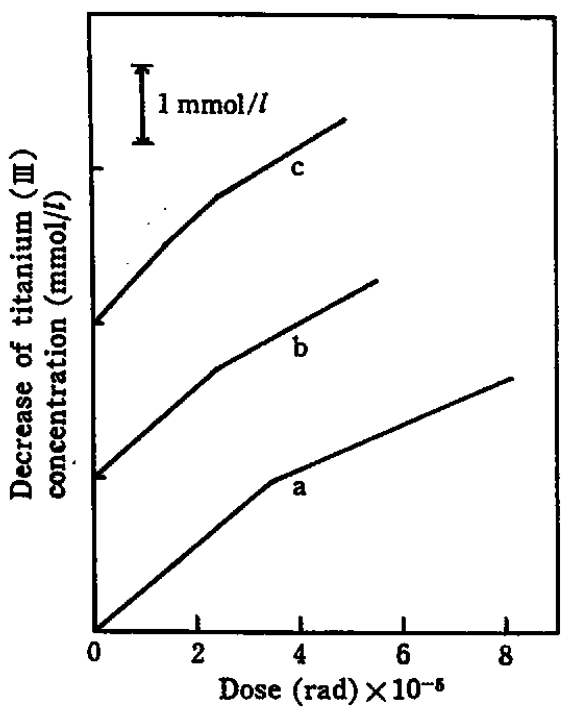

Fig. 7 Relation between dose irradiated and decrease of titanium(III) concentration on changing dose rate

Dose rate $(\mathrm{rad} / \mathrm{hr}) \longrightarrow a: 9.5, b: 2.0$, c $: 0.27$ Initial titanium (H) concentration : $4.2 \mathrm{mmol} / l$,

Sulfuric acid concentration $: 0.8 \mathrm{~N}$

したがって，碳酸チタン(III)線量計としては，各G值のうちで 相対標淘偏差が $\pm 2.3 \%$ ともっとも精度のよい $G_{1}\left(\mathrm{Ti}^{4+}\right)$ 值の部 分を用いるのが適当である。

\section{4 考察}

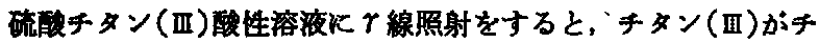
タン(V)へ酸化される。この酸化反応機構化ついて $G\left(\mathrm{Ti}^{4+}\right)$ 值 をもとにして考えてみる。

水の放射線分解婂よって生成される酸化羁元に関与する中間体 としては，酸性溶液中で注溶媒和電子は水素イオンと反応して承 来原子になることが明らかになっているので，ラジカル生成物の 水莱原子と水酸ラジカルおよび分子生成物の水素分子と過酸化水 来であると考えられる。これらの中間体とチタン(II)イオンとの 间炕は空気が存在しない硫酸鉄(II)溶液の場合19と同侎につぎの

19） J.W.T. Spinks，R. J. Woods，“放射線化学入門”，痋業図 ㄴ.
反応が起こると予想される。

$$
\begin{gathered}
\cdot \mathrm{OH}+\mathrm{Ti}^{3+} \longrightarrow \mathrm{Ti}^{4+}+\mathrm{OH}^{-} \\
\mathrm{H}_{2} \mathrm{O}_{2}+\mathrm{Ti}^{3+} \longrightarrow \mathrm{Ti}^{4+}+\cdot . \mathrm{OH}+\mathrm{OH}^{-} \\
\cdot \mathrm{H}+\mathrm{H}^{+}+\mathrm{Ti}^{3+} \longrightarrow \mathrm{Ti}^{4+}+\mathrm{H}_{2}
\end{gathered}
$$

以上の反応似より生成されるチタン (N)の収率を化学量論的に 表わすと

$$
G\left(\mathrm{Ti}^{4+}\right)=2 G_{\mathrm{H}_{2} \mathrm{O2}}+G_{\mathrm{H}}+G_{\mathrm{OH}}
$$

となる。ここで, Allen'苂によって求められたそれぞれの初期収 率, $G_{\mathrm{H}}=3.65 、 G_{\mathrm{OH}}=2.95$ ，および $G_{\mathrm{H}_{2} \mathrm{O}_{2}}=0.80$ の値を (4) 式 に代入すると， $G\left(\mathrm{Ti}^{4+}\right)$ は 8.20 となる。これは表 3 の線量率が 小さいときの照射初期における $G_{0}\left(\mathrm{Ti}^{4+}\right)$ の值とほぼ等しい。し かし，大線貫を照射すると生成したチタン(N)イオンが水素原子 に対してつぎのような酸化反応をすると教えられる。

$$
\cdot \mathrm{H}+\mathrm{Ti}^{4+} \longrightarrow \mathrm{Ti}^{\mathbf{4 +}}+\mathrm{H}^{+}
$$

硫酸チタン (正) 線量計のG值として用いる $G_{1}\left(\mathrm{Ti}^{4+}\right)$ が 5.76 となったのは，照射線量が比較的大きく（3）式と（5）式の競争 反応が起ころためである。 $G_{1}\left(\mathrm{Ti}^{4+}\right)$ の值から逆算すると，この項 域では(3)式の反応が(5)式のそれに対して 1/3だけまさってい ることになる。さらに大線量の領域では， $G_{2}\left(\mathrm{Ti}^{4+}\right)$ が 3.86 であ ることから(5)式の反応の方が約 $1 / 6$ だけ大きと推定される。

また， $G\left(\mathrm{Ti}^{4+}\right)$ 値が変化する点は表 $1 ， 2 ， 3$ のよ5にチタン (III)とチタン(N)の此が任一定であることから，チタン系の酸 化還元電位に依存するすのと考えられる。しかし $G\left(\mathrm{Ti}^{4+}\right)$ 值が 不車続的に変化することについてはさらに検討が必要である。

\section{5 結䇺}

硫酸チタン(III) 線量計 $\left(G_{1}\left(\mathrm{Ti}^{4+}\right)=5.76 \pm 0.13\right)$ は Fricke 線 量計にくらべてつぎのような利点がある。

（1）線量の連続的自動測定が可能である。

（2）チタン（而）初期濩度 $42 \mathrm{mmol} / l$ の溶液を用いれは $2 \times$ $10^{6} \mathrm{rad}$ の大線量まで测定できる。

（3）試料溶液は電解還元することによって簡単に何回です再 調製できる。

20) A. O. Allen, "The Radiation Chemistry of Water and Aqueous Solutions", Van Norstrand, New York(1961) p. 41 .

\section{Titanium (III) Sulfate Dosimeter Using Amperometry \\ Masashi Goto, Yoshio IDora and Daido IsHII \\ Department of Applied Chemistry, Faculty of Engineering, Nagoya \\ University ; Chikusa-ku, Nagoya-shi, Japan}

When a sulfuric acid aqueous solution of titanium(III) sulfate is irradiated by ${ }^{\circ 0} \mathrm{Co} \gamma$-rays, titanium(III) is oxidized to titanium $(N)$ through the radiolysis producsts of water. The che- 
mical dosimeter based on the decrease of titanous ion was investigated to measure continually and automatically a relatively large dose. The oxidized amounts of titanium(II) were determined amperometrically.

The dropping mercury electrode and $\mathrm{Hg} \mid \mathrm{Hg}_{2} \mathrm{SO}_{4}$ reference electrode were found to be stable to the irradiation of $\gamma$-rays. There was the linear relation having several crooks between the decrease of titanium(III) concentration and the quantity of irradiation. The $G\left(\mathrm{Ti}^{4^{+}}\right)$ value was independent of the initial titanium(III) concentration, sulfuric acid concentration, and irradiation intensity. The $G$ value from the origin to the first crook was $5.76 \pm 0.13$ except the weak irradiation region. The measurable dose range increased with the elevation of the initial titanium(III) concentration. When the solution of $42 \mathrm{mmol} / l$. was used, the dose of $2 \times 10^{8} \mathrm{rad}$ could be measured. The sample solution was reproduced easily by the electrolytic reduction.

\title{
熱分解ガスクロマトグラフィーによる高分子物質の迅速分析
}

\author{
(1971 年8月 12 日受理)
}

奥 本 忠興* - 武内 次夫**

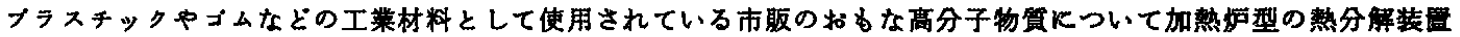

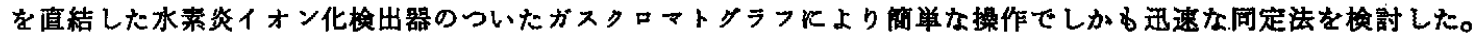
本実験では熱分解温度は $530^{\circ} \mathrm{C}$ と一定にして，またカラムの稙類やガスクロ マトグラフの測定条件す一定にして行 なった。熱分解のさい，高分子物貿は低沸点物から高沸点物まで広い籍囲にわたって生成するので,カラムは年温さ せて分解生成物を分離させた。個々の高分子飞特徽的なパイログラムのパターンが得られ，これらのパターンおよび おるな分解生成物の相対生成率とから種ヶの高分子を判別し同定することができた。また単独重合体についてはもノ マーの生成率怙上び熱分解機構から分類して若千の考察を行なった。
\end{abstract}

\section{1 藉 夆}

最近の高分子化学の発展により種々の嵪分子物畝が開発され， その種類も多岐にわたっている。高分子物質の判別飞は古くから 燃焼試験や溶解試験および融点测定などの分析法が用いられてお。 り、これらの方法はいくらかよい情報を与えるが，類似したボり マーの同定にはかなり困難である。また最近，赤外吸叔スペクト ルが高分子分析に有力な手段として沉用されてきてはいるがこ の方法では高分子物質をらすいフィルムにするか，スペクトルに 妨害とならない暗当な溶媒に溶かすか，または粉末の場合は $\mathrm{KBr}$ で錠剂にする必要があるばかりでなく，この方法で恃識別が困難 な場合が少なくない。また NMR スペクトルる高分子分析使用 されているが，この方法は一般に試料調製がやっかいであり，測 定される陚料す限定されている。

ガスクロマトグラフィーはその分析手段としての有用性をここ であらためて強調する必要むない注琴在広く利用されているが， 個々の高分子について岋熱分解ガスクロマトグラフィー (PGC) による一連の系統的な高分子についての報告122) はわずかにみら れる程度である。この原因としては一般に高分子物質は熱分解す

* 名古垔ゴム株式会社技術部, 知紧西春日井郡春日村

** 名古屋大学工学部, 名古畤市千種区不老町

1) B. C. Cox, B. Ellis, Anal. Chem., 36, 90(1964).

2) B. Groten, ibid., 36, 1204(1964).
ると㕕い範囲の分解物を生成するため分解生成物を同時に検出す ることが困難であること，および最適の分解温度は㑭々の高分子 でまちまちであることなどがあげられる。

最近 Cox 5) は PGC K上り加熱炉型の 分解乑置を用いて分 解温度 $700^{\circ} \mathrm{C}$ で高分子物質の同定を行なっでり，カラム温度 は $0^{\circ} \mathrm{C}$ および $17^{\circ} \mathrm{C}$ の低温で操作している。また Groten ${ }^{2)}$ は PGC により多くの高分子材料を分析する方法を研究しており， そこでは白金フィラメント法により $950^{\circ} \mathrm{C} の$ 比輘的高蕰で熟分

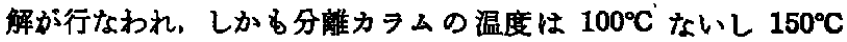
で一定である。両者の研究とも分離カラAを比較的低い一定温度 で操作することにより，比較的低沸点物のるを分離，検出してい る。またパイログラム上の特るな特有ピークの謴属恃なされて特 らず，指紋的なパイログラムのパターンから高分子を同定してい る。

本報では市眅されている大部分の代表的な高分子物質について 加熱炻型の熱分解装置を直結したガスクロストグラフを用いて熱 分解温度, カラムの種類やガスクロマトグラフなとの操作来件は 一定炕たもち，しかも分離カラムは $50^{\circ} \mathrm{C}$ から $210^{\circ} \mathrm{C}$ までを毎分 $16^{\circ} \mathrm{C}$ の速度で界温させて低沸点から高沸点にわたる広い筑囲の 熱分解生成物を網羅したパイログラムを得た。これらのパイログ ラムおよび同定したおすな分解生成物の相対生成率とからそれぞ れの高分子物の珜別および同定する方法を検討しだ。 